\title{
Cortical Cell Layer of the Cerebral Cortex
}

National Cancer Institute

\section{Source}

National Cancer Institute. Cortical Cell Layer of the Cerebral Cortex. NCI Thesaurus. Code C49136.

Cerebral tissue composed of cells with distinctive characteristics. The cerebral cortex contains six cell layers. 